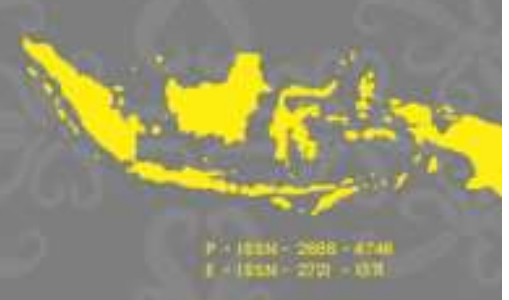

\title{
Analisis Potensi Ekowisata Berbasis Masyarakat di Desa Burai Sumatera Selatan
}

\author{
Alditia Detmuliati \\ Politeknik Negeri Sriwijaya, Palembang 30139, Indonesia \\ alditia.detmuliati@polsri.ac.id
}

\begin{abstract}
In 2021 the Province of South Sumatra brought home 8 awards at the Anugrah Pesona Indonesia. One of them was awarded second place in the Burai Village award in the category of Most Popular Ecotourism Village in Indonesia. This research was conducted to explore the potential of ecotourism in Burai Village. This study uses a communitybased research (CBR) approach which is implemented with a Participatory Action Research (PAR) approach. Some of the potentials found include building floating / nonpermanent buildings on the river, make Lima's house and Bari house a homestay. , Pindang and Kemplang are special foods that can be enjoyed by tourists., Songket and Purun are souvenirs from Burai Village, bummer dance as performance in Burai Village, offers several activities on community agricultural land without having to change the contents of the agricultural land.
\end{abstract}

\section{ABSTRAK}

Pada tahun 2021 Provinsi Sumatera Selatan memboyong pulang 8 penghargaan pada Anugrah Pesona Indonesia. Salah satunya yang mendapatkan penghargaan Desa Burai peringkat kedua pada katagori Kampung Ekowisata Terpopuler di Indonesia. Penelitian ini dilakukan bertujuan menggali potensi ekowisata di Desa Burai. Penelitian ini menggunakan pendekatan community-based research (CBR) yang diimplementasikan dengan pendekatan Participatory Action Research (PAR). Beberapa potensi yang ditemukan antara lain lain: membangun bangunan apung / tidak permanen di sungai kelakar. menjadikan rumah Limas dan Rumah Bari sebagai homestay. pindang dan Kemplang menjadi makanan khas yang dapat dinikmati oleh wisatawan. Songket dan Purun menjadi oleh-oleh Desa Burai. Tari Bumme sebagai pertunjukan di Desa Burai. Menawarkan beberapa aktifitas dilahan pertanian masyarakat tanpa harus merubah isi dari lahan pertanian tersebut

\section{ARTICLE HISTORY}

Submitted:28.06.2021

Revised:29.06.2021

Accepted:08.07.2021

Online first:10.07.2021

\section{KEYWORDS}

Ecotourism,

Tourist village, tourism potential

\section{KATA KUNCI}

Ecowisata

Desa wisata,

Potensi Pariwisata 


\section{Pendahuluan}

Sumatera Selatan didirikan pada tanggal 12 September 1950 yang awalnya mencakup Jambi, Bengkulu, Lampung dan Kepulauan Bangka. Namun pada akhirnya keempat wilayah tersebut memisahkan diri dan membentuk provinsi masing-masing. Sumatera Selatan juga dikenal dengan julukan Bumi Sriwijaya sejak berabad lalu. Hal ini tidak terlepas dari sejarah yang menyatakan bahwa pada abad ke 7 hingga abad ke 12 Masehi wilayah Sumatera Selatan merupakan pusat Kerajaan Sriwijaya. Berdasarkan prasasti Sriwijaya yang dikenal sebagai Prasasati Kedukan Bukit menunjukan bahwa Kota Palembang merupakan kota tertua di Indonesia yang berumur 1339 tahun.

Sumatera Selatan merupakan salah satu provinsi di pulau Sumatera yang pernah beberapa kali ditunjuk menjadi tuan rumah dalam perhelatan olahraga tingkat nasional dan internasional di Indonesia. Pemerintah Sumatera Selatan mempersiapkan pengembangan pariwisata secara serius.

Mei 2021, Sumatera Selatan Memboyong 8 penghargaan pada Anugrah Pesona Indonesia (API) 2020. Delapan pengahragaan itu antara lain : 1) Festival Danau Ranau sebagai terbaik 1, acara Festival pariwisata terpopuler di Indonesia. 2) SKY LAND di Musi Banyuasin (Muba) sebagai terbaik 1 untuk event Olahraga Pariwisata Terpopuler di Indonesia. 3) Bakarang di MUBA sebagai terbaik 1, Event Wisata air Terpopuler di Indonesia, 4) Kopi Semendo dari Muara Enim, sebagai terbaik ke dua Minuman Tradisional Terpopuler di Indonesia, 5) Kampung Warna Warni Burai di Ogan Ilir (OI) sebagai terbaik kedua Kampung Ekowisata Terpopuler di Indonesia. 6) Dusun Sri Pengantin di Musirawas (Mura) sebagai terbaik kedua destinasi unik terpopuler di Indonesia. 7) Tangga Butung di Palembang sebagai terbaik ketiga Destinasi Belanja Terpopuler di Indonesia. 8) Desa Pelang Kenidai di Pagaralam sebagai terbaik ke tiga Kampung Adat Terpopuler di Indonesia

Desa Burai berada di Kabupaten Ogan Ilir dapat dijangkau dari Kota Palembang melalui akses toll Indralaya dengan waktu tempuh sekitar 40menit. Terpilihnya Desa Burai menjadi Kampung Wisata Kedua Terpopuler dalam ajang penghargaan Anugrah Pesona Indonesia (API) 2020 akan menarik perhatian wisatawan sekitar Desa Burai dan Sumatera Selatan. 
Edutourism Journal of Tourism Research I p-ISSN: 2686-4746 | e-ISSN: 2721-1371

Tidak mudah bagi sebuah kelompok masyarakat untuk menerima kedatangan orang asing disekitar pemukiman mereka. Beberapa ketakutan yang mungkin akan dirasakan kelompok masyarakat seperti wisatawan melakukan hal yang tidak baik, wisatawan membawa budaya baru dan akan mempengaruhi budaya yang sudah ada. Salah satu solusi yang bisa dilakukan yang itu menggali potensi wisata yang ada di Desa Burai dengan melibatkan masyarakat setempat.

B.Setiawan (2021) dalam penelitian Pengembangan Desa Ekowisata Burai Yang Tangguh Bencana menyimpulkan bahwa Desa Ekowisata Burai memiliki potensi kebakaran yang minim namun memiliki potensi banjir yang cukup signifikan. Dalam penelitian tersebut direkomendasikan untuk pengembangan wilayah bagian barat daya karena memiliki potensi bencana geo-meteorologi yang paling rendah.

Asmoro, A,Y dalam penelitian Analisis Potensi Wisata Desa Dengan Kerangka 6A Studi Kasus Desa Ngajum, Malang memberikan kesimpulan beberapa hal yang dapat dilaksanakan di Desa Ngajum antara lain : 1). Wahana Tirta (Lahan Desa A). 2) Ekowisata/Agrowisata (Lahan Desa B). 3) Perkebunan Kopi. 4) Factory Tour di Pabrik Susu Greenfield. 5) Padepokan Soerjo Alam. 6) Swafoto di lansekap persawahan dan 7). Ritual Kebudayaan Masyarakat

Melihat dan menimbang hasil dari penelitian terkait, Desa Burai perlu digali lebih dalam potensi potensi ekowisata yang tersedia dilokasi tersebut.

\section{Review Tinjauan Pustaka}

\section{Desa Wisata}

Desa Wisata didefinisikan sebagai sebagian atau keseluruhan wilayah desa yang dimiliki potensi, produk dan aktivitas wisata yang dapat dimanfaatkan untuk pengembangan pariwisata dan dikelola oleh kelompok masyarakat di desa secara berkelanjutan (Ida Bagus Suryawan, 2015:9).

Komponen pembentuk desa wisata tediri atas :

1. Wilayah Desa. Sebuah desa wisata haruslah menjadi bagian dari wilayah satu desa. Bilamana sebuah kegiatan wisata mencakup lebih dari satu wilayah desa, 
kegiatan wisata tersebut dapat digolongkan kedalam wisata perdesaan dan bukannya desa wisata.

2. Produk pariwisata. Sebuah desa wisata haruslah memiliki produk wisata sebagai bentuk objek material dari proses perdagangan barang dan jasa yang dilakukan kepada wisatawan. Produk pariwisata yang ada dan ditawarkan oleh sebuah desa wisata dapat berupa atraksi wisata, jasa wisata maupun usaha pariwisata yang ada di desa.

3. Organisasi pengelola. Keberadaan organisasi pengelola merupakan hal yang wajib pada sebuah desa wisata. Ketidaktersedianya organisasi pengelola menjadi sebuah jaminan bahwa tidak ada legitimasi dari sebuah pihak yang memanfaatkan dan mengelola sumber daya pariwisata dengan mengatasnamakan organisasi desa. Organisasi desa wisata yang dibentuk haruslah memilki kewenangan dan mewakili keberadaan desa, dan diketahui serta disahkan oleh stakeholder di desa baik itu peringkat pemerintahan desa, badan pengawas desa, kelompok organisasi kemasyarakat di desa maupun perwakilan masyarakat desa.

\section{Pengembangan Pariwisata}

Pengembangan pariwisata merupakan kata yang cukup tinggi penggunannya di Negara maupun dan level apapun, tetapi kelihatannya dipahami secara berbeda-beda. Pengembangan mengisyaratkan suatu proses evolusi dengan konotasi positif atau sekurang-kurangnya bermakna "tidak jalan di tempat'. Perbedaan interpretasi terjadi karena kata pengembangan dapat dikaitkan dengan dua hal, yakni : "proses" dan “tingkat" perkembangan sesuatu. Menurut Yoeti (1996:172), ada tiga hal yang perlu diperhatikan dalam mengembangkan objek wisata, yaitu :

1. Adanya "Something to see" yaitu daerah tersebut harus memiliki daya Tarik wisata atau atraksi wisata yang berbeda dengan yang dimiliki daerah yang lain.

2. Adanya "Something to do" yaitu daerah tersebut memiliki fasilitas yang dapat membuat wisatawan betah tinggal lebih lama di tempat itu.

3. Adanya "Something to buy " yaitu objek wisata tersebut harus memiliki sesuatu yang bisa dibeli oleh wisatawan sebagai sebuah kenang-kenangan atau cidera mata/souvenir. Jadi pengembangan pariwisata merupaka 
Edutourism Journal of Tourism Research I p-ISSN: 2686-4746 | e-ISSN: 2721-1371

\section{Ekowisata}

Ekowisata merupakan kegiatan pariwisata yang bertanggung jawab secara lingkungan dan alam, memberikan kontribusi yang positip terhadap konservasi lingkungan dan memperhatikan kesejahteraan masyarakat lokal Ekowisata merupakan salah satu aspek yang sangat terkait dengan lingkungan, perkembangangan diharapkan mampu melestarikan sumber daya alam dan lingkungan (Suksma, 2009). Banyak kajian telah dilakukan terkait dengan ekowisata, namun secara umum perkembangan ekowisata sangat terkait dengan pelestarian lingkungan dan budaya suatu daerah.

\section{Potensi Ekowisata}

Potensi dalam kepariwisataan dapat diartikan sebagai suatu modal atau aset yang dimiliki oleh suatu daerah tujuan wisata dan dapat diekploitasi untuk kepentingankepentingan ekonomi yang secara ideal terangkum didalamnya perhatian terhadap aspek-aspek budaya. Suarka (2010) menjelaskan bahwa potensi wisata adalah segala sesuatu yang terdapat disuatu daerah yang dapat dikembangkan menjadi daya tarik wisata, potensi tersebut dapat dibagi dua yaitu potensi budaya dan potensi alamiah. Potensi budaya meliputi potensi yang tumbuh dan berkembang di masyarakat seperti adat istiadat, mata pencaharian dan kesenian, sedangkan potensi alamiah adalah potensi yang berupa potensi fisik, geografis alam, termasuk jenis flora dan fauna pada suatu daerah.

Ekowisata merupakan kegiatan pariwisata yang bertanggung jawab secara lingkungan dan alam, memberikan kontribusi yang positip terhadap konservasi lingkungan dan memperhatikan kesejahteraan masyarakat lokal Ekowisata merupakan salah satu aspek yang sangat terkait dengan lingkungan, perkembangangan diharapkan mampu melestarikan sumber daya alam dan lingkungan (Suksma, 2009). Banyak kajian telah dilakukan terkait dengan ekowisata, namun secara umum perkembangan ekowisata sangat terkait dengan pelestarian lingkungan dan budaya suatu daerah.

Dari definisi potensi dan ekowisata diatas dapat ditarik kesimpulan bahwa potensi ekowisata adalah suatu modal atau aset (baik berupa potensi budaya dan alamiah) yang dimiliki oleh suatu daerah, yang dapat dikembangkan untuk kegiatan wisata yang bertanggung jawab secara lingkungan, memberikan kontribusi yang positip terhadap konservasi lingkungan, dan meningkatkan perekonomian masyarakat sekitar. 


\section{Metodologi Penelitian}

Kajian ini merupakan community-based research (CBR) yang diimplementasikan dengan pendekatan Participatory Action Research (PAR). Ini merupakan salah satu pilihan dalam metodologi penelitian kualitatif deskriptif dengan integrasi metode dan observasi, dokumentasi, analisis, dan penafsiran terhadap pola, atribut, dan fenomena yang diteliti (Buckles, 2019; MacDonald, 2012). PAR merupakan bagian dari penelitian tindakan, dimana pengumpulan dan analisis data dilakukan secara sistematis dengan tujuan mengambil tindakan dan membuat perubahan, sekaligus mampu menghasilkan pengetahuan praktis (Gillis \& Jackson, 2002, p. 264).

\section{Hasil dan Diskusi}

\section{a. Desa Burai}

Desa Burai merupakan 1 dari 21 Desa/ Kelurahan terletak di Kabupaten Ogan Ilir yang lebih tepatnya $10 \mathrm{~km}$ kearah selatan kecamatan Tanjung Batu. Desa Burai berbatasan dengan desa dan satu kelurahan. Bagian utara berbatasan dengan Desa Tanjung Batu, bagian Barat berbatasan dengan desa Sentul, bagian timur berbatasan dengan Desa Tanjung Sejaro dan Bagian selatan berbatasan dengan kelurahan Tanjung Batu. Desa Burai beikllim tropis dengan musim hujan dan musim kemarau. Desa Burai dikelilingi sungai dan rawa yang menjadikan Mayoritas masyarakat Burai berprofesi sebagai nelayan, petani dan pengrajin khas Burai ( Songket dan Purun). Pada tahun 2020 tercatat Desa Burai memiliki penduduk dengan jumlah sekitar 2103 jiwa yang tersebar dalam 6 wilayah Dusun.

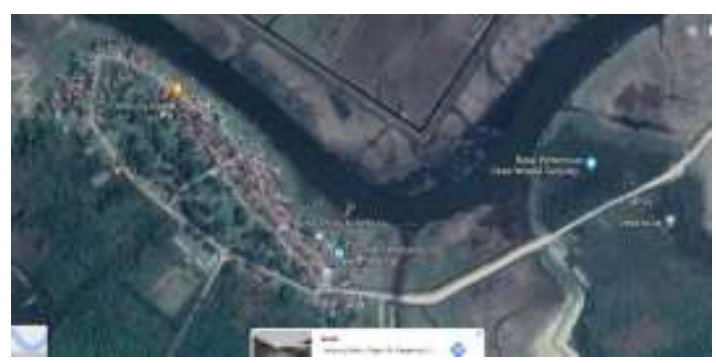

Gambar 1. Peta Desa Burai 


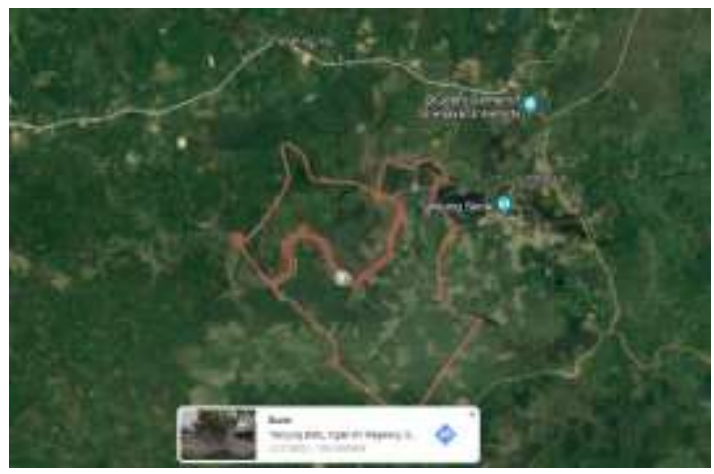

Gambar 2. Perkampungan Desa Burai

Berada didaerah yang terpencil yang dikelilingi sungai dan rawa membentuk Desa Burai menjadi desa yang unik dan asri. Desa Burai berada cukup dengan dengan komplek perkantoran pemerintahan Kabupaten Ogan Ilir (OI) dengan waktu tempuh kurang lebih 15menit dengan kendaraan bermotor. Sepanjang perjalanan sekali-sekali berpapasan dengan kendaraan lainnya, namun tidak banyak, Hal ini dikarenakan jalan ini merupakan jalan desa Burai. Beberapa masyarakat kecamatan lain terkadang melewati Desa Burai untuk mempersingkat waktu tempuh dan jarak. Sisanya jalan ini hanya diakses oleh masyarakat Desa Burai.

Di desa Burai, penduduk menempati rumah limas dan rumah panggung yang sudah berumur lebih dari 4 generasi dan masih terawat. Rumah yang didirikan tepat dibibir Sungai Burai seringkali menjadikan rumah seperti terapung dan menyatu dengan sungai. Masyarakat Desa Burai memiliki ratusan sapi yang dilepas begitu saja di sekitar pemukiman masyarakat. Sebagian besar masyarakatnya juga memiliki keahlian dalam menenun kain songket, membuat kemplang dari ikan segar sungai desa Burai dan kerajinan tangan lainnya.

Desa Burai bertransformasi menjadi desa ekowisata sejak tahun 2017 dengan melihat potensi yang dimiliki Desa Burai yang diawali oleh program inisiatif masyarakat serta bantuan dari Dinas Pariwisata Provinsi Sumatera Selatan, Pemerintah Kabupaten Ogan Ilir, BUMN dan Lembaga lainnya.

Desa Burai dikembangkan dengan Langkah awal menjadi Desa Burai kampung warna warni. Kampung warna warni ini dibuat dengan pengecetan warna warni jalan setapak 
Edutourism Journal of Tourism Research I p-ISSN: 2686-4746 | e-ISSN: 2721-1371

didalam desa, tempat ibadah dan perumahan penduduk dipinggiran sungai kelakar.pada tahap awal tersebut masyarakat desa melakukannya secara bergotong royong.

Untuk menunjang pengembangan pariwisata di desa Burai pada tahun 2018 Kepala Desa Burai membentuk kelompok Sadar Wisata dengan Nomor:140/KEP/KD-BR/2018 dan pada tahun 2020 Kepala Desa Burai membentuk Badan Usaha Milik ( BUM) Desa Burai dengan nomor : 140/KEP/KD-BR/2020.

Pada tahun 2020, Desa Burai menutup diri dari kunjungan wisatawan sebagai salah satu Langkah untuk memutuskan mata rantai penyebaran virus pandemic covid19. Namun Desa Burai tetap berbenah diri dan mempersiapkan Desa Burai untuk kunjungan wisatawan selanjutnya. Selama tahun 2020 Desa Burai mendapatkan pendampingan Perguruan Tinggi berbasis Cleanliness ( Kebersihan ), Health (Kesehatan), Safety ( Keamanan) dan Environment Sustainability ( Kelestarian Lingkungan) yang lebih dikenal dengan singkatan CHSE.

Sejak awal 2021, Desa Burai mulai membuka diri dan menerima kunjungan wisatawan. Desa Burai menerima wisatawan berkelompok ( grup ) dengan pemesanan terlebih dahulu. Salah satu alasannya agar Desa Burai dapat mengontrol aktifitas, interaksi dan protokol kesehatan wisatawan dengan masyarakat setempat

\section{b. Potensi - potensi Desa Burai}

Desa Burai memiliki sejarah dan kebudayaan yang tinggi. Selain itu potensi alam Desa Burai semakin menjadi alasan kuat untuk mengembangkan potensi ekowisata dalam rangka menjaga kebudayaan dan keaslian Desa Burai. Beberapa potensi Desa Burai yang ditemukan dilapangan :

a. Sungai Kelakar

Sungai Kelakar merupakan sungai yang mengeliling Desa Burai. Masyarakat Burai mengandalkan Sungai Kelakar sebagai salah satu mata pencaharian sebagai nelayan. Sungai Kelakar memiliki berbagai jenis ikan bahkan udang sungai yang juga menjadi salah satu komoditi utama pembuatan makanan khas Desa Burai. Potensi lainnya Sungai Kelakar yaitu dapat dibangun beberapa sarana wisata seperti 
warung apung, dermaga apung ( bukan bangunan permanen) dan wahana water sport (Perahu dayung dan perahu wisata).

b. Rumah Limas dan Rumah Bari

Di Desa Burai ditemukan rumah Limas dan Rumah Bari yang telah berusia 200 tahun yang saat ini dihuni oleh generasi ke empat sang pemilik rumah, Jika dilihat sekilas, Rumah Limas dan Rumah Bari hampir terlihat sama. Sama-sama berbentuk panggung dan terbuat dari kayu, namun perbedaan terlihat dari bentuk atap. Rumah limas atapnya berbentuk limas sementara rumah bari berbentuk atap rumah pada umumnya.

Rumah Limas dan Rumah Bari ini dapat dijadikan homestay yang kemudian disewakan kepada wisatawan.

c. Pengolahan Makanan

Masyarakat Desa Burai memiliki kebudayaan yang tinggi. Beberapa kebudayaan yang masih terjaga di Desa Burai. Perempuan Desa Burai pintar dalam mengolah makanan. Hal ini dibuktikan perempuan Desa Burai hingga saat ini masih terlatih memasak Pindang Salai, Kemplang Ikan dan Udang serta masakan lainnya. Pindang merupakan makanan khas masyarakat Sumatera Selatan dengan bahan utama nya ikan, bumbu dapur dan nenas serta daun kemangi sebagai pelengkapnya. Sementara kemplang mirip dengan kerupuk yang terbuat dari ikan atau udang yang telah diolah dan dicampur dengan bahan lainnya yang kemudian tahap pengolahan terakhir digoreng atau dipanggang.

Pindang dan Kemplang ini dapat menjadi santapan wisatawan selama berada di Desa Burai maupun dibawa pulang sebagai oleh-oleh.

d. Kerajinan

Sumatera Selatan terkenal dengan pengrajin Songket. Bahkan songket merupakan buah tangan yang wajib dibawa kembali ke daerah asal sebagai oleh-oleh dari Sumatera Selatan. Perempuan Desa Burai menenun songket mengisi waktu luang mereka. Songket Desa Burai juga diperjualbelikan di sentra songket di Kota Palembang. Songket Desa Burai memiliki motif yang berbeda dengan Songket dari daerah lain di Sumatera Selatan. Selain Songket, perempuan Desa Burai juga memiliki tangan yang lincah dalam membuat kerajinan tangan berbahan Purun. 
Purun adalah tanaman yang tumbuh liar didekat air atau rawa gambut dan banyak ditemukan di Desa Burai. Purun Kering akan dikreasikan oleh Perempuan Desa Burai menjadi tas, sendal, topi dan kerajinan tangan lainnya. Kerajinan ini bisa dijadikan cinderamata khas Desa Burai.

e. Kesenian

Desa Burai memiliki tari tradisional Bumme. Tarian ini mengajak masyarakat untuk Bertani. Tarian ini dapat dijadikan pertunjukan bagi wisatawan yang berkunjung ke Desa Burai.

f. Lahan Pertanian

Desa Burai memiliki lahan pertanian yang luas. Sebagian besar kondisi lahan pertanian ini rawa-rawa dan gambut. Pada musim kemarau, rawa-rawa ini akan kering dan berbentuk lapangan luas, namun Ketika musim hujan, rawa-rawa ini akan menjadi danau yang luas. Lahan yang berada cukup tinggi dari permukaan air, dijadikan masyarakat sebagai perkebunan karet. Ini bisa dimanfaatkan oleh masyarakat Desa Burai sebagai salah satu atraksi wisata penarik wisatawab berkunjung ke Desa Burai.

Pada musim kemarau, lapangan luas ini dapat dimanfaatkan sebagai venue untuk beberapa kegiatan seperti perkemahan, festival layang-layang dan festival lainnya. Memasuki musim hujan, rawa-rawa mulai dipenuhi air dan puncaknya menjadi danau bahkan membanjiri perkampungan Desa Burai. Wilayah ini bisa menjadi kolam pancing bagi wisatawan. Masyarakat bisa menawarkan perahu melengkapi pengalaman memancing di Desa Burai. Perkebunan Karet bisa dijadikan sarana olahraga seperti ATV, Buggy, MotoCross, Offroad, Paintball (perang-perangan). Selain itu Desa Burai juga memiliki lahan yang dditanami buah-buahan dibantu oleh Kementrian Kehutanan. Masyarakat juga dapat menjadikan kebun karet dan kebun buah-buahan sebagai wisata edukasi. Wisatawan dapat ikut serta saat panen raya. 
Edutourism Journal of Tourism Research I p-ISSN: 2686-4746 | e-ISSN: 2721-1371

\section{Kesimpulan}

Menjadi sebuah Kampung Ekowisata tentulah tidak semudah dibayangkan. Menerima kunjungan wisatawan bisa saja menjadi boomerang bagi kebudayaan dan lingkungan Desa Burai. Pengembangan Desa bisa saja meninggalkan bahkan menghilangkan keaslian. Setelah menganalisis kondisi di Desa Burai ditemukan beberapa potensi wisata yang bisa dilakukan dengan memperhatikan kaidah-kaidah ekowisata.

Beberapa potensi yang dapat dikembangkan antara lain: 1) membangun bangunan apung / tidak permanen di sungai kelakar. 2). Menjadikan rumah Limas dan Rumah Bari sebagai homestay. 3). Pindang dan Kemplang menjadi makanan khas yang dapat dinikmati oleh wisatawan. 4) Songket dan Purun menjadi oleh-oleh Desa Burai. 5). Tari Bumme sebagai pertunjukan di Desa Burai. 6). Menawarkan beberapa aktifitas dilahan pertanian masyarakat tanpa harus merubah isi dari lahan pertanian tersebut. 
Edutourism Journal of Tourism Research | p-ISSN: 2686-4746 | e-ISSN: 2721-1371

\section{Author's declaration}

\section{Authors' contributions and responsibilities}

$\checkmark$ The authors made substantial contributions to the conception and design of the study.

$\sqrt{ }$ The authors took responsibility for data analysis, interpretation and discussion of results.

$\sqrt{ }$ The authors read and approved the final manuscript.

\section{Availability of data and materials}

$\sqrt{ }$ All data are available from the authors.

\section{Competing interests}

$\sqrt{ }$ The authors declare no competing interest. 
Edutourism Journal of Tourism Research I p-ISSN: 2686-4746 | e-ISSN: 2721-1371

\section{References}

[1] Asmoro.,Y.A, Bachri,T.B.,Detmuliati,A.2020.Analisis Potensi Wisata Desa Dengan Keragka 6A Studi Kasus Desa Ngajum, Malang. Media Wisata. Yogyakarta.

[2] A, Yoeti, Oka.1996.Pengantar Ilmu Pariwisata, Angkasa,Bandung

[3] B. Setiawan, M.Addiansyah, S.N. Jati, Harnan, E.D. Mayasari, E.W.D. Hastuti.2021.Pengembangan Desa Ekowisata Burai Yang Tangguh Bencana

[4] Buckles, D. (2019). Participatory action research: Theory and methods for engaged inquiry.Journals.Sagepub.Com. https://doi.org/10.4324/9781351033268

[5] Butler, R. W. (2019). Tourism carrying capacity research: a perspective article. Tourism Review, 75(1), 207-211. https://doi.org/10.1108/TR-05-2019- 0194

[6] Gillis, A., \& Jackson, W. (2002). Research for nurses : methods and interpretation. F.A. Davis Co. http://search.ebscohost.com/login.aspx? direct $=$ true $\&$ scope $=$ site $\& d b=$ lebk $\& d b=$ nlabk $\& A N=82216$

[7] Haryanto, J. T. (2014). Model Pengembangan Ekowisata Dalam Mendukung Kemandirian Ekonomi ISSN 16935969 Media Wisata, Volume 18, Nomor 2, November 2020 EISSN 26858436244 https://amptajurnal.ac.id/index.php/MWS Daerah Studi Kasus Provinsi Diy. Jurnal Kawistara, 4(3). https://doi.org/10.22146/kawistara.6383

[8] Sukma Arida, Nyoman. 2009. Meretas Jalan Ekowisata Bali (Proses Pengembangan, Parisipasi Lokal dan Tantangan Ekowisata di Tiga Desa Kuno Bali). Denpasar. Universitas Udayana.

[9] Trisnawati, Linda.2021. Sumsel Raih 8 Penghargaan Anugerah Pesona Indonesia Award 2020, Sandiaga Uno akan Datang ke Burai OI.Tribun Sumsel. 